\title{
Landspítali á farsóttartímum
}

Í janúarhefti Læknablaðsins var viðtal við leiðarahöfund par sem varað var við stórslysi á bráðamóttöku Landspítala vegna pess að deildin var daglega yfirfull af sjúklingum sem biðu innlagnar. Mikil umræða varð í samfélaginu í kjölfarið sem náði meðal annars inn í sali Alpingis. Embætti landlæknis gerði úttekt og að beiðni heilbrigðisráðuneytis var sett á fót nefnd sem gerði tillögur til ráðherra í lok febrúar síðastliðins. Framkvæmdastjórn Landspítala fjallaði um tillögurnar og sampykkti.

Á Landspítala er að öllu jöfnu starfandi farsóttanefnd sem hafði verið að auknum störfum frá í janúar vegna útbreiðslu kórónaveirusýkingar (SARS-CoV-2 ) í Wuhan-borg í Kína. Með hliðsjón af ofangreindu ástandi virtist útlitið uggvænlegt. Pá brast á með heimsfaraldri COVID-19. Spítalinn fór á hættustig og viðbragðsstjórn (sambland af farsóttanefnd og framkvæmdastjórn undir forystu forstjóra) gjörbreytti skipulagi og starfsemi spítalans; legudeildum og gjörgæsludeildum var breytt í farsóttadeildir og bráðamóttökur bjuggu sig undir að taka á móti COVID-19 staðfestum og grunuðum sjúklingum. Рað sem mestu skipti varðandi umönnun COVID-19-sjúklinga var að sérstök göngudeild var sett á laggirnar í einu úthúsi spítalans í Fossvogi. Par fór saman pétt samstarf hóps lækna og hjúkrunarfræðinga með aðkomu heilbrigðisupplýsingatæknideildar í samstarfi við aðila utan spítalans. Spítalinn bjó sig pannig undir verstu hugsanlegu spár um próun faraldursins.

Pá gerist hið óvænta! Hjúkrunarheimili opnaði og tók á móti mörgum sjúklingum frá Landspítala, samfélagið hljóðnaði og komum sjúklinga á spítalann fækkaði um 5-10\% eftir starfsstöðvum. Komum á bráđamóttökur fækkaði um 8,5\% (pessi próun hélst áfram í apríl en gögn liggja ekki fyrir). Flæði sjúklinga frá bráđamóttöku á legudeildir varð greiðara. Hreyfiteymi, sem sinnti sjúklingum á bráðamóttökunni sem voru í bið eftir vist á legudeild, hefur verið lagt af. Öll valstarfsemi í heilbrigðispjónustunni var lögð af með reglugerð heilbrigðisráðuneytis frá 23. mars til 31. maí.

Pegar petta er ritað lítur út fyrir að spítalinn og heilbrigðiskerfið geti vel sinnt pví álagi sem COVID19-sjúkdómurinn hefur lagt á íslenskt samfélag. Næsta viðfangsefni er: hvernig verður best snúið til baka? Augljóslega parf heilbrigðiskerfið, par með talið Landspítali, að sinna lögbundnu hlutverki sínu (pjónusta, kennsla og vísindi). Par verða ákvarðanir sóttvarnalæknis ráđgefandi um samspil starfsfólks, nema og sjúklinga eftir pví sem við verður komið. En, COVID-19-faraldurinn er ekki búinn! Landspít- ali parf að vera tilbúinn til að bregðast við, fari faraldur af stað á ný eða stök tilfelli koma upp. Margt er á huldu um framvindu faraldursins og fjölmörgum spurningum ósvarað hvað hana varðar.

Í frábærri grein sem birtist í tímaritinu Science 14. apríl síðastliðinn er leitast við að svara spurningum um framhaldið eftir að heimsfaraldursástandi linnir. Höfundarnir nota áætlanir um árstíðasveiflur, mótefnasvar og víxlverkun mótefnasvara milli betakórónaveiranna OC43 og HKU1 og SARS-CoV-2 (af sömu ættkvísl) til að búa til spálíkan um smit SARSCoV-2 í bandaríska samfélaginu. Höfundarnir gefa sér við gerð spálíkansins að af afloknum heimsfaraldri verði veiran að öllum líkindum virk í samfélögum (í tempruðum löndum) að vetrarlagi. Peir spá pví að núverandi fyrirkomulag um breyttar venjur fólks í samfélaginu (reglur um nánd, hópa og svo framvegis) muni purfa að vera til staðar fram á árið 2022 að gefnum forsendum spálíkansins. Auðvitað mun pað ekki gilda um alla pví á pessu tímabili munu ávallt einhverjir smitast og verða ónæmir. Рað er hins vegar ekki vitað hversu lengi mótefni peirra eru virk til að vernda gegn SARS-CoV-2 sýkingu síðar né með hvaða hætti ætti að auðkenna pá.

Раð er einkum tvennt sem stendur uppúr hvað reynslu af faraldrinum á Landspítala áhrærir. Í fyrsta lagi að starfsmenn spítalans hafa lyft grettistaki við að breyta skipulagi og aðstöðu til að bregðast við aðsteðjandi vá. Hins vegar mikilvægi pess að varðveita og hagnýta pann lærdóm sem faraldurinn hefur fært okkur, um pað með hvaða hætti má til framtíðar próa pjónustu við skjólstæðinga Landspítala og víðar í heilbrigðiskerfinu.

\section{Heimildir}

1. Gunnarsdóttir GA. Stórslys í aðsigi á bráðamóttökunni. Læknablaðið 2020; 106: 3.

2. Tillögur átakshóps til að leysa úr vanda bráđamóttöku Landspítala. Heilbrigðisráðuneytið, 25. febrúar 2020. stjornarradid.is/efst-a-baugi/ frettir/stok-frett/2020/02/25/Tillogur-atakshops-til-ad-leysa-ur-vandabradamottoku-Landspitala/ - apríl 2020.

3. Strategic preparedness and response plan. World Health Organization. who.int/publications-detail/strategic-preparedness-and-response-planfor-the-new-coronavirus - apríl 2020.

4. Göngudeild nú í Birkiborg. mbl.is/frettir/burdargrein/2020/03/24/gongudeild_nu_i_birkiborg/ - apríl 2020.

5. Starfsemisupplýsingar Landspítala jan-mars 2020. Óbirt

6. Frestun valkvæðra skurðaðgerða vegna Covid-19. Heilbrigðisráðuneytið, 22. mars 2020. stjornarradid.is/efst-a-baugi/frettir/stok-frett/2020/03/22/ Frestun-valkvaedra-skurdadgerda-vegna-Covid-19/ - apríl 2020.

7. Kissler SM, Tedijanto C, Goldstein E, Grad YH, Lipsitch M. Projecting the transmission dynamics of SARS-CoV-2 through the postpandemic period. Science $2020 ; 14$. april.

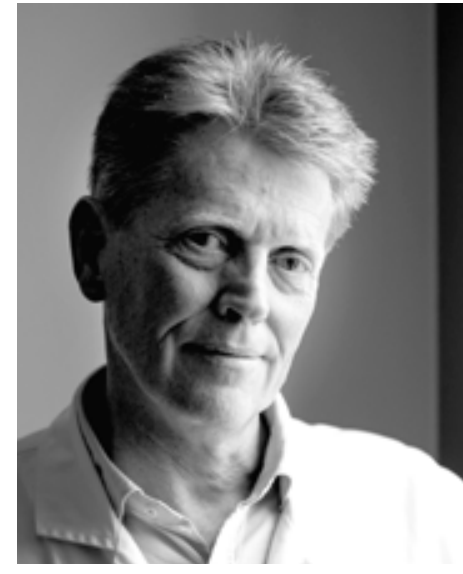

Már Kristjánsson

yfirlæknir smitsjúkdómalækninga Landspítala

klínískur prófessor, læknadeild Háskóla Íslands

markrist@landspitali.is

Landspitali - National University Hospital during an epidemic

Már Kristjánsson, MD Chief, department of Infectious Diseases Landspitali - National University Hospital Clinical professor, University of Iceland Medical School 